Seminar Nasional Teknologi Informasi dan Kedirgantaraan (SENATIK)

Vol. II, 26 November 2016, ISSN: 2528-1666

\title{
Studi Tentang Upaya Peningkatan Jumlah dan Kualifikasi Teknisi Pesawat Udara Di Indonesia
}

\author{
Nurhadi $^{1}$, Wowo Rossbandrio ${ }^{2}$ \\ ${ }^{1}$ Politeknik Negeri Malang, ${ }^{2}$ Politeknik Negeri Batam \\ ${ }^{1}$ J1. Soekarno Hatta 9, Malang \\ 1nurhadiabuzaka@gmail.com
}

\begin{abstract}
The development of the aviation industry in Indonesia increased significantly the last few years, so it is necessary adequate Aircraft Technician/Engineer (TPU), both the number and qualifications. The problem is, the amount of TPU in Indonesia is very limited and the majority academic level only senior high school, it making less competitive. The purpose of study to find out efforts to increase the number and qualifications of TPU by PT GMF Aero Asia Garuda Group (GMFAA) is cooperating with six universities in Indonesia to produce TPU with D-III level.Studies done by observation, interview and direct involvement at the Basic Aircraft Maintenance (BAM) for instructor, organized by GMFAA for 1,920 hours. The data were analyzed descriptively to obtain qualitative research. The study shows that in the first batch (2015-2016) has trained 16 lecturers of 6 universities to conduct AMTO class at each campus. In the first year (2015) has opened AMTO classes at six campuses with 226 students and 216 in the second year (2016). From the 4th year (2018) will certainly be produced aircraft technician/engineer with D-III qualifiers at least 200 people, so it's very helpful to accelerate the fulfillment of TPU in Indonesia
\end{abstract}

Keywords: Aircraft Technician/Engineer, maintenance, AMTO

\section{Pendahuluan}

Kebutuhan tenaga professional di sektor penerbangan saat ini sangat besar karena industripenerbangan berkembang pesat beberapa tahun terakhir.

Santoso Edi Wibowo, Kepala Badan Pengembangan Sumber Daya Manusia (BPSDM) Kementrian Perhubungan, merilis data CMO 2013-Boeing yang menyatakan bahwa hingga tahun 2030, dunia membutuhkan 980.799 pilot, 1.164 .969 Teknisi Pesawat Udara (TPU), dan 139.793 ATC (Air Traffic Controller), Sementara itu, di negara-negara Asia Tenggara dibutuhkan 47.700 TPU dan 42.200 pilot sampai tahun 2029. Kebutuhan Indonesia diperkirakan 10 persennya dari angka kebutuhan di ASEAN atau 4.770 TPU, 4.220 pilot,dan 1.000 ATC[1]. Sementara menurut Toto Soebandroro, Direktur Quality, Safety dan Security Sriwijaya Air, hingga tahun 2016 diperkirakan Indonesia masih kekurangan 7.500 tenaga teknisi [2]. Lebih jauh
Richard Budihadianto, Presiden Indonesia Aircraft Maintenance Shop Asosiation (IAMSA) mengatakan bahwa kebutuhan industri perawatan pesawat di Indonesia 5 tahun ke depan diperkirakan mencapai 6.000 orang, atau minimal 1.000 orang pertahun, sementara institusi pendidikan di Indonesia hanya mampu mencetak 600 orang tenaga ahli bidang perawatan pesawat [3].

Sayangnya, perkembangan industri penerbangan yang signifikan tersebut tidak diikuti ketersediaan tenaga teknisi pesawat udara yang memadai, baik jumlah maupun kualifikasinya. Saat ini jumlah keseluruhan teknisi dan tenaga ahli perawatan pesawat di Indonesia diperkirakan di bawah tiga ribu orang, sehingga kebutuhan teknisi pesawat hingga beberapa tahun kedepan memang sangat besar. Hal ini juga bisa dipahami, karena menurut (Toto:2015) bahwa kebutuhan pilot dan TPU itu tidak bisa sembarangan disediakan oleh lembaga pendidikan penyediaSumber 
Daya Manusia (SDM),sehingga tidak heran jika ketersediaan pilot dan TPU sangat terbatas. Masalahnya lagi ternyata mayoritas TPU dan tenaga ahli (engineer)perawatan pesawat udara di Indonesia masihberkualifikasi STM/SMK/D-II, dan sangat sedikit yang berkualifikasi D-III/S-1, sangat berbeda dengan TPU dan engineerdi luar negeri yang minimal berkualifikasi S-1, sehingga TPU dan engineer di Indonesia kurang berdaya saing.

Oleh karena itu perlu dilakukan terobosan untuk mengatasi kebutuhan TPU dan engineer untuk menjawab tantangan industri pesawat udara tersebut. Salah satu lembaga penyedia TPU atau disebut AMTO (Aircraft Maintenance Training Organization-Lembaga training tenaga ahli perawatan pesawat) dan juga MRO di Indonesia yang telah melakukan terobosan adalah PT. GMF Aero Asia Jakarta-Garuda Group (GMFAA).

Tujuan studi untuk mengetahui upaya peningkatan penyediaan TPU yang dilakukan oleh GMFAA sebagai salah satu AMTO besar di Indonesia yangtelah melakukan kerjasama dengan 6 Perguruan Tinggi di Indonesia dengan membuka program D-III Bidang perawatan Pesawat Udara dan Basic Certificate. Program ini bertujuanuntuk menghasilkan TPU berkualifikasi D-III yang memenuhi Peraturan Keselamatan Penerbangan Sipil (Civil Aviation Safety Regulation/CASR 65), dimana lulusannyaakan langsung mendapatkan ijazah D-III dan Basic Certificate sesuai CASR 65, sehingga benar-benar siap bekerja, memiliki kompetensi yang sesuai, dan bersertifikasi internasional [4].

\section{Metode Penelitian}

Penelitian ini menggunakan metode penelitian deskriptif korelasional, yaitu metode untuk menggambarkan dan mencari hubungan antar variabel bebas terhadap variabel terikat[5]. Variabel bebas berupa upaya-upaya yang telah dilakukan PT GMFAA dalam meningkatkan jumlah dan kualifikasi teknisi pesawat udara di Indonesia, dan variabel terikat berupa hasil kegiatan yang dilakukan. Subyek penelitian yaitu peserta BAM (Basic Aircraft Maintenance)Dosen sebanyak 16 orang, dan 6 Perguruan Tinggi di Indonesia penyelenggara program D-III AMTO kelas kerjasama dengan GMFAA. Teknik sampel menggunakan total sampling, yaitu semua populasi dijadikan sampel. Pengumpulan data menggunakan metode observasi, wawancara, dan keterlibatan langsung dalam kegiatan pada BAM Dosen. Wawancara dilakukan untuk memperoleh data pelaksanaan program D-IIIAMTO kelas kerjasama di 6 Perguruan Tinggi, meliputi jumlah mahasiswa dan pelaksanaan program yang sudah dan atau sedang berlangsung.

\subsection{Tempat studi}

Studi dilakukan di GMFAA khususnya bagian Learning services, Hangar 1, Hangar 2, Hangar 3, Hangar 4, Engine Shop dan juga di Terminal 2 Bandara Juanda Surabaya.

\subsection{Waktu Studi}

Studi dilakukan dalam kurun waktu 1 (satu) tahun penyelenggaraan program BAM Dosen yaitu sejak 10 Februari 2015 hingga 9 Februari 2016.

\subsection{Metode Analisis Data}

Data yang diperoleh melalui observasi dan wawancara kemudian dianalisis secara deskriptif untuk mendapatkan hasil penelitian kualitatif berupa upaya peningkatan kualifikasi teknisi pesawat udara di Indonesia.

\section{Hasil dan Pembahasan}

Pada bagian ini diberikan data tentang pelaksanaan BAM Dosen dan BAM D-III kelas kerjasama (AMTO) GMFAA dengan 6 Perguruan Tinggi di Indonesia.

\subsection{Program BAM Dosen}

BAM Dosen merupakan program pertama di Indonesia yang dilakukan oleh GMFAA. Program ini bertujuan untuk menyiapkan calon-calon instruktur AMTO kelas kerjasama dari unsur Dosen Perguruan Tinggi yang bekerjasama membuka kelas AMTO tersebut. Setelah menyelesaikan program ini, peserta akan mendapatkan sertifikat General Licence (GL) yang diakui secara internasional, sehingga memenuhi persyaratan untuk mengajar dikelas AMTO.

Pada angkatan I yang dilaksanakan mulai 10 Februari 2015 hingga 9 Februari 2016, program ini diikuti oleh 16 Dosen dari 6 Perguruan Tinggi (4 Politeknik dan 2 Universitas) dengan data sebagaimana Tabel 1. 
Tabel 1Data Peserta BAM Dosen

\begin{tabular}{|l|l|l|}
\hline No & Nama Dosen & Asal Perguruan Tinggi \\
\hline 1 & $\begin{array}{l}\text { Ari Wibowo, S.T., } \\
\text { M.Eng }\end{array}$ & $\begin{array}{l}\text { Politeknik Negeri } \\
\text { Batam }\end{array}$ \\
\hline 2 & $\begin{array}{l}\text { Dwi Kartikasari, S.T., } \\
\text { MBA }\end{array}$ & $\begin{array}{l}\text { Politeknik Negeri } \\
\text { Batam }\end{array}$ \\
\hline 3 & $\begin{array}{l}\text { Wowo Rosbandrio, Dipl. } \\
\text { Ing }\end{array}$ & $\begin{array}{l}\text { Politeknik Negeri } \\
\text { Batam }\end{array}$ \\
\hline 4 & $\begin{array}{l}\text { Positron Bangun, S.T., } \\
\text { M.T. }\end{array}$ & $\begin{array}{l}\text { Politeknik Negeri } \\
\text { Medan }\end{array}$ \\
\hline 5 & $\begin{array}{l}\text { Sony Hestukoro, S.T., } \\
\text { M.T. }\end{array}$ & $\begin{array}{l}\text { Politeknik Negeri } \\
\text { Medan }\end{array}$ \\
\hline 6 & $\begin{array}{l}\text { Eka Satria M, B.Eng } \\
\text { (Hons)., M.T. }\end{array}$ & $\begin{array}{l}\text { Politeknik Negeri } \\
\text { Sriwijaya Palembang }\end{array}$ \\
\hline 7 & $\begin{array}{l}\text { Drs. Irawan Malik, } \\
\text { MSME }\end{array}$ & $\begin{array}{l}\text { Politeknik Negeri } \\
\text { Sriwijaya Palembang }\end{array}$ \\
\hline 8 & Maskuri, S.T., M.T. & $\begin{array}{l}\text { Politeknik Negeri } \\
\text { Malang }\end{array}$ \\
\hline 9 & $\begin{array}{l}\text { Nurhadi, S.Pd., SST., } \\
\text { M.T }\end{array}$ & $\begin{array}{l}\text { Politeknik Negeri } \\
\text { Malang }\end{array}$ \\
\hline 10 & $\begin{array}{l}\text { Riyanto Heri N, S.T., } \\
\text { M.T. }\end{array}$ & $\begin{array}{l}\text { Politeknik Negeri } \\
\text { Malang }\end{array}$ \\
\hline 11 & $\begin{array}{l}\text { Utsmansyah A., S.T., } \\
\text { M.T. }\end{array}$ & $\begin{array}{l}\text { Politeknik Negeri } \\
\text { Malang }\end{array}$ \\
\hline 12 & Amat Chaeroni, S.T. & Unsurya Jakarta \\
\hline 13 & $\begin{array}{l}\text { Bismil Rabeta., S.T., } \\
\text { M.T. }\end{array}$ & Unsurya Jakarta \\
\hline 14 & Heri Kiswanto, S.T. & Unsurya Jakarta \\
\hline 15 & Hendrix N F, S.T., M.T. & STTA Yogyakarta \\
\hline 16 & $\begin{array}{l}\text { Teguh Wibowo., S.T., } \\
\text { M.T. }\end{array}$ & STTA Yogyakarta \\
\hline S & be Lina, 2015[6] & \\
\hline
\end{tabular}

Sumber: Linda, 2015[6]

Seluruh peserta BAM Dosen tersebut menjalani pelatihan teori di Bagian Learning services dan praktek di Hangar 1, Hangar 2, Hangar 3, Hangar 4, dan Engine Shop GMFAA Jakarta serta OJT di berbagai Bandara di Indonesia. Aktivitas pelatihan BAM Dosensebagaimana Gambar 1 sampai dengan Gambar 6.

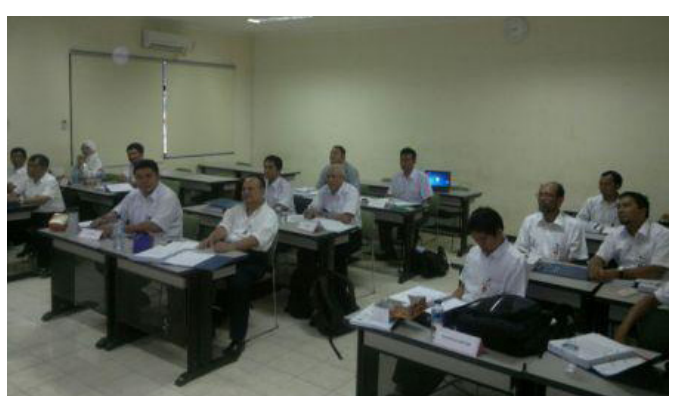

Gambar 1Pelatihan teori di kelas

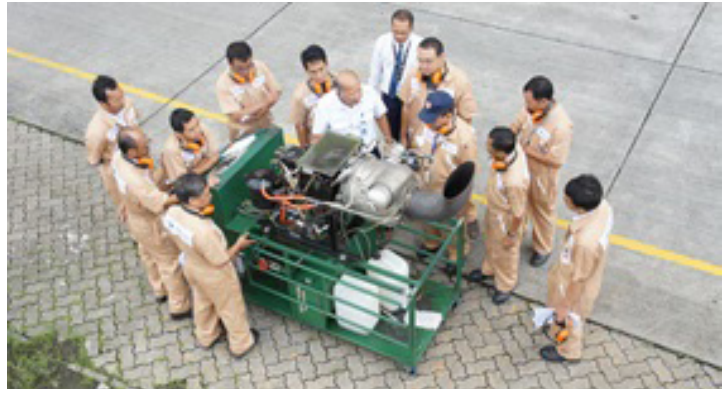

Gambar 2Praktek run up engine

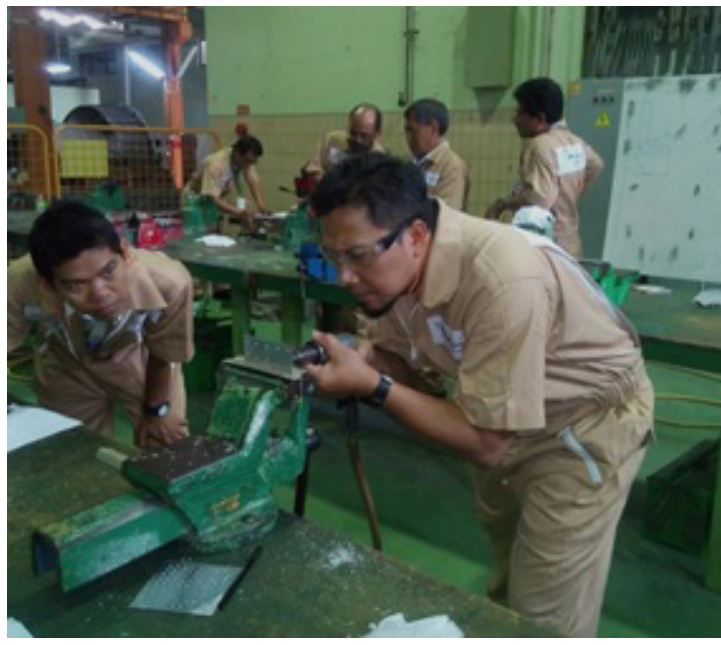

Gambar 3 Praktek riveting

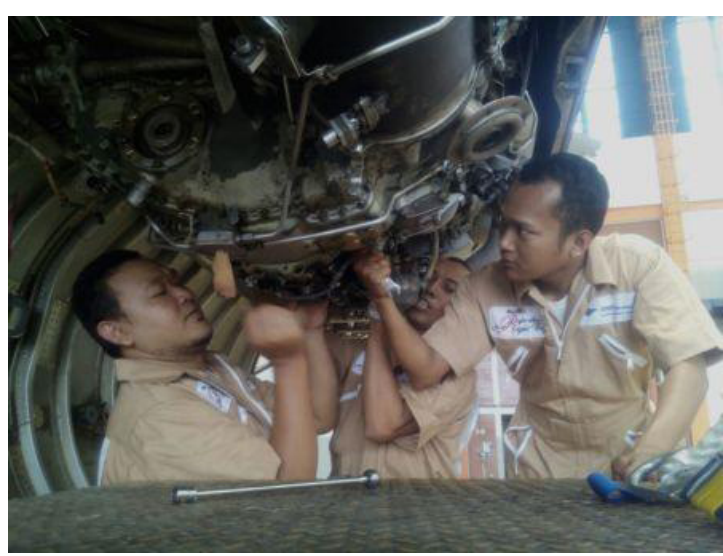

Gambar 4 Praktek engine di Hangar 2 


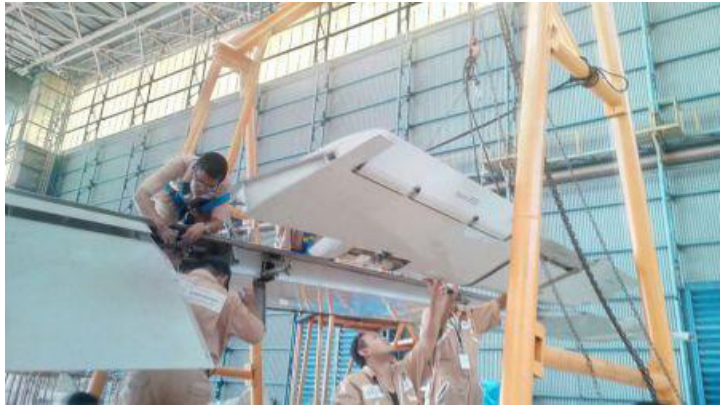

Gambar 5 Praktek penyetelan flight control

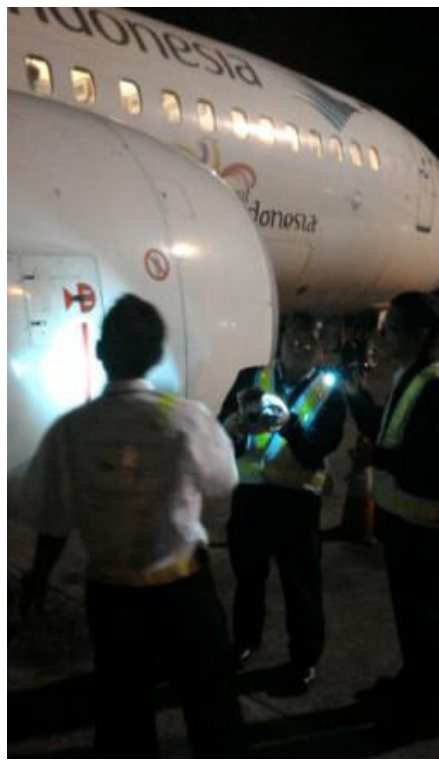

Gambar 6 OJT di Bandara

Peserta BAM Dosen ini mengikuti program pelatihan Basic Aircraft Maintenance selama 1 tahun (1.920 jam) terdiri dari teori, praktek dan OJT (On The Job Training)yang dibagi dalam 3 phase. Masingmasing phase dilaksanakan selama 3-4 bulan.

Pelatihan teori dan praktek dilaksanakan di Departemen Learning Services GMFAA, Hangar 1, Hangar 2, Hangar 3, dan Hangar 4, sedangkan OJT dilaksanakan di beberapa bandara di kota asal peserta, yaitu: Bandara Hang Nadim Batam, Bandara Kuala Namu Medan, Bandara Sultan Mahmud Badaruddin Palembang, Bandara Halim Perdanakusuma Jakarta, Bandara Adisucipto Yogyakarta dan Bandara Juanda Surabaya.

Materi pelatihan yang diberikan pada program BAM Dosen yaitu materi standar kelas AMTO sebagaimana Tabel 2.
Tabel 2. Materi Pelatihan BAM Dosen Phase 1-3

\begin{tabular}{|c|c|c|c|}
\hline No. & Phase & Subject/Task & $\begin{array}{c}\text { Duration } \\
\text { Hours }\end{array}$ \\
\hline 0 & 1 & Orientation Training & 24 \\
\hline 1 & 1 & Electrical Fundamental & 12 \\
\hline 2 & 1 & Electronic Fundamental & 12 \\
\hline 3 & 1 & Digital Techniques & 16 \\
\hline 4 & 1 & $\begin{array}{l}\text { Practical Electrical } \\
\text { Fundamental }\end{array}$ & 4 \\
\hline 5 & 1 & $\begin{array}{l}\text { Practical Electronic } \\
\text { Fundamental }\end{array}$ & 4 \\
\hline 6 & 1 & $\begin{array}{l}\text { Practical Digital } \\
\text { Techniques }\end{array}$ & 8 \\
\hline 7 & 1 & $\begin{array}{l}\text { Aerodynamics \& Flight } \\
\text { Control }\end{array}$ & 16 \\
\hline 8 & 1 & Practical Aerodynamics & 8 \\
\hline 9 & 1 & Material Hardware & 24 \\
\hline 10 & 1 & $\begin{array}{l}\text { Practical Material } \\
\text { Hardware }\end{array}$ & 80 \\
\hline 11 & 1 & Aircraft System & 40 \\
\hline 12 & 1 & Practical Aircraft System & 104 \\
\hline 13 & 1 & Human Factors Initial & 32 \\
\hline $13 a$ & 1 & On The Job Training & 160 \\
\hline $13 b$ & 1 & Self Learning & 160 \\
\hline $13 c$ & 1 & Verification & 40 \\
\hline $13 d$ & 1 & Oral test & 40 \\
\hline 14 & 2 & Maintenance Practice & 40 \\
\hline 15 & 2 & Aircraft Structure & 24 \\
\hline 16 & 2 & $\begin{array}{l}\text { Practical Maintenance } \\
\text { Practices }\end{array}$ & 136 \\
\hline 17 & 2 & Practical Aircraft Structure & 96 \\
\hline 18 & 2 & Aviation Legislation & 40 \\
\hline 19 & 2 & Aircraft Instrument & 16 \\
\hline 20 & 2 & $\begin{array}{l}\text { Practical Aircraft } \\
\text { Instrument }\end{array}$ & 16 \\
\hline $21 a$ & 2 & On The Job Training & 160 \\
\hline $21 b$ & 2 & Self Learning & 160 \\
\hline $21 c$ & 2 & Verification & 40 \\
\hline $21 d$ & 2 & Oral test & \\
\hline 21 & 3 & Gas Turbine Engine & 16 \\
\hline 22 & 3 & Propeller & 8 \\
\hline 23 & 3 & $\begin{array}{l}\text { Practical Gas Turbine } \\
\text { Engine }\end{array}$ & 80 \\
\hline 24 & 3 & Practical Propeller & 8 \\
\hline 25 & 3 & Management Maintenance & 40 \\
\hline
\end{tabular}


Lanjutan Tabel 2

\begin{tabular}{|l|l|l|l|}
\hline No. & Phase & \multicolumn{1}{|c|}{ Subject/Task } & $\begin{array}{c}\text { Duration } \\
\text { Hours }\end{array}$ \\
\hline $25 a$ & 3 & On The Job Training & 160 \\
\hline $25 b$ & 3 & Self Learning & 160 \\
\hline $25 c$ & 3 & Verification & 40 \\
\hline $25 d$ & 3 & Oral test & \\
\hline & & Total Hours & 1920 \\
\hline
\end{tabular}

Sumber: Fuad, 2016 [7]

Setelah menyelesaikan program pelatihan BAM Dosen selama 1920 jam tersebut, peserta berkewajiban mengikuti Ujian General Licence (GL) yang diselenggarakan oleh DKUPPU (Direktorat Kelaikan Udara dan Penerbangan Pesawat Udara) Kementerian Perhubungan Republik Indonesia, untuk memperoleh sertifikatGL, sehingga alumni BAM Dosen benar-benar kompeten dan memenuhi persyaratan mengajar di kelas AMTO.

Program BAM Dosen ini adalah program yang sangat baik dan tepat dalam rangka penyiapan kelas AMTO di Perguruan Tinggi, karena dengan mengirimkan Dosen untuk mengikuti training ini, Perguruan Tinggi akan memiliki Dosen yang bersertifikasi internasional, sehingga dapat menyelenggarakan kelas AMTO guna menghasilkan lulusan yang kompeten untuk menjadi TPU dan engineer yang sangat dibutuhkan dunia penerbangan Indonesia,

\subsection{Program BAM D-III Kelas Kerjasama}

Program BAM D-III Kelas Kerjasama merupakan program yang digagas oleh GMFAA bersama 6 Perguruan Tinggi di Indonesia untuk memenuhi kebutuhan TPU di Indonesia, yaitu:

1. Politeknik Negeri Batam

2. Politeknik Negeri Medan

3. Politeknik Negeri Sriwijaya Palembang

4. Politeknik Negeri Malang

5. Universitas Surya Darma (Unsurya) Jakarta

6. Sekolah Tinggi Teknologi Adisutjipto (STTA) Yogyakarta

Program ini bertujuan untuk menghasilkan lulusan yang kompeten dibidang perawatan pesawat udara yang memiliki kualifikasi ijazah D-III dan bersertifikasi internasional. Setelah lulus dari programD-III Kelas Kerjasama ini, makalulusan akan mendapatkan ijazah D-III dan sertifikat General Licence (GL) yang diakui secara internasional, sehingga memenuhi persyaratan untuk tenaga ahli perawatan pesawat udara sesuai CASR 65 .

Program D-III Kelas Kerjasama ini telah dibuka mulai tahun 2015 di 6 Perguruan Tinggi tersebut dan saat ini sudah berjalan dua angkatan(batch). Batch I (2015) dan Batch II (2016). Ada dua program yang dibuka yaitu Airframe Powerplant (AP) dan Electrical Avionic (EA). Data jumlah mahasiswa kelas kerjasama sebagaimana Tabel 3.

Tabel 3. Data jumlah mahasiswa D-III kelas kerjsama

\begin{tabular}{|l|l|l|l|l|}
\hline No & Nama Perguruan Tinggi & $\begin{array}{l}\text { Batch } \\
\text { I } \\
2015\end{array}$ & $\begin{array}{l}\text { Batch } \\
\text { II } \\
2016\end{array}$ & Ket \\
\hline 1 & Politeknik Negeri Batam & 24 & 24 & AP \\
\hline 2 & $\begin{array}{l}\text { Politeknik Negeri } \\
\text { Medan }\end{array}$ & 22 & 22 & AP \\
\hline 3 & $\begin{array}{l}\text { Politeknik Negeri } \\
\text { Sriwijaya Palembang }\end{array}$ & 48 & 48 & $\begin{array}{l}\text { AP, } \\
\text { EA }\end{array}$ \\
\hline 4 & $\begin{array}{l}\text { Politeknik Negeri } \\
\text { Malang }\end{array}$ & 48 & 48 & $\begin{array}{l}\text { AP, } \\
\text { EA }\end{array}$ \\
\hline 5 & Unsurya Jakarta & 65 & 48 & AP \\
\hline 6 & STTA Yogyakarta & 22 & 24 & EA \\
\hline & Jumlah & 229 & 214 & \\
\hline
\end{tabular}

Mahasiswa Program D-III AMTO Kelas Kerjasama melaksanakan perkuliahan teori dan praktek di kampus masing-masing. Pada waktuwaktu tertentu dilakukan kunjungan ke GMFAA. Foto kegiatandan perkuliahan mahasiswa D-III AMTO kelas kerjasama sebagaimana Gambar 7 sampai dengan Gambar 11.

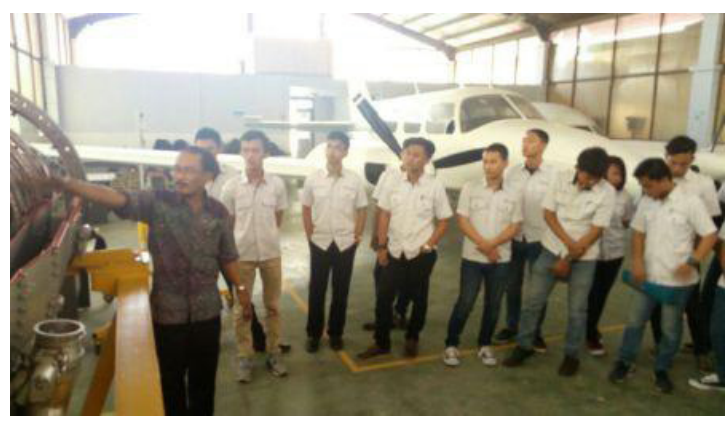

Gambar 7 Kegiatan mahasiswa AMTO di Politeknik Negeri Batam (Penjelasan praktek engine) 


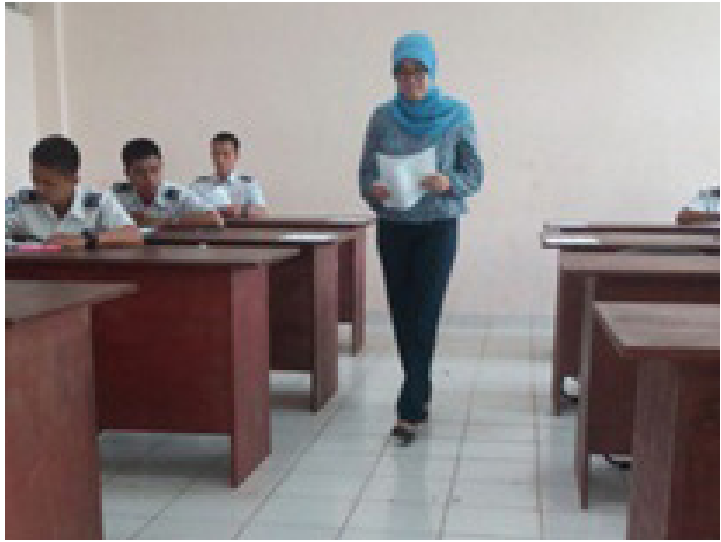

Gambar 8 Kegiatan mahasiswa AMTO di Politeknik Negeri Sriwijaya

(Examination)

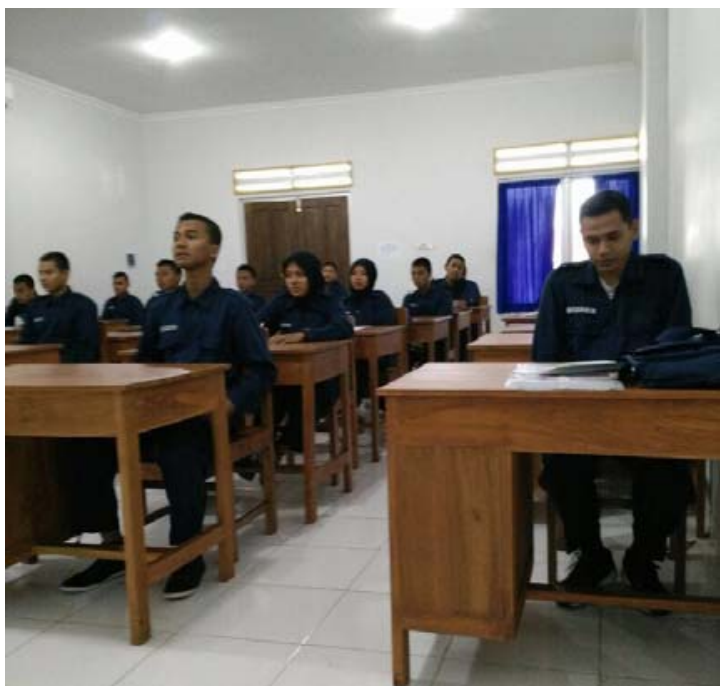

Gambar 9 Kegiatan mahasiswa AMTO di STTA Yogyakarta (kuliah teori)

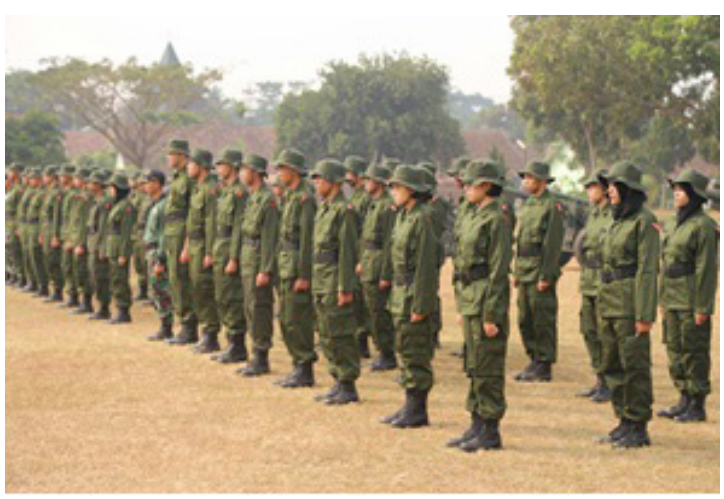

Gambar 10 Kegiatan mahasiswa AMTO di Politeknik Negeri Malang (latihan kedisiplinan)

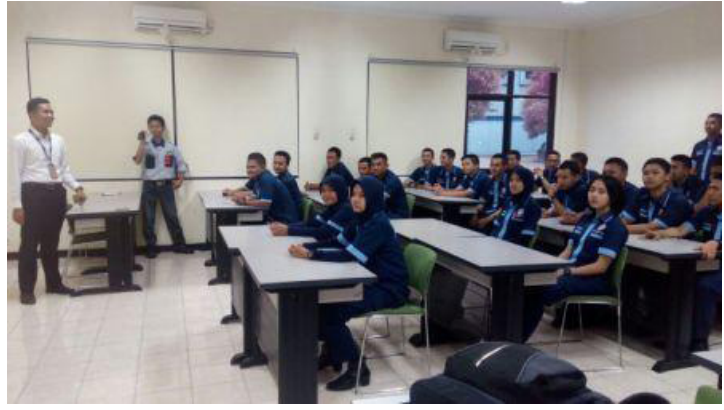

Gambar 11 Kegiatan mahasiswa AMTO di Politeknik Negeri Malang (kunjungan ke GMFAA)

Kurikulum Program D-III Kelas Kerjasama menggunakan kurikulum khusus yang diolah dari kurikulum kelas AMTO dan kurikulum program D-III di Perguruan Tinggi sehingga memenuhi standar DKPPU dan DIKTI. Contoh kurikulumDIII AMTO kelas kerjasama sebagaimana Tabel 4.

\subsection{Analisis Peningkatan Jumlah Teknisi Pesawat Udara di Indonesia}

Berdasarkan data pada Tabel 3, jumlah mahasiswa AMTO kelas kerjasama sebanyak 229 (2015) dan 214 (2016). Jumlah tersebut dapat terus meningkat pada tahun berikutnya seiring dengan kebutuhan yang terus meningkat dan menyesuaikan ketersediaan peralatan dan kapasitas kelas AMTO.

Sebagaimana diketahui bahwa program AMTO kelas kerjasama adalah program D-III (kuliah 3 tahun/6 semester), maka mulai tahun 2018 program tersebut akan meluluskan mahasiswa Angkatan I sebanyak 229 orang (atau minimal 200 orang).

Berdasarkan kajian pustaka sebelumnya bahwa kondisi saat ini kebutuhan teknisi ratarata 1.000 orang/tahun, dan kemampuan lembaga pendidikan penerbangan menghasilkan teknisi sebanyak 600 orang/tahun, maka kekurangannya sebesar 400 orang/tahun. Artinya bahwa terjadi Gap antara supply dan demand sebesar 400 orang/tahun. Dengan demikian, program D-III AMTO kelas kerjasama mampu memenuhi kebutuhan teknisi sebesar 200 orang/tahun $(50 \%$ dari total kebutuhan yang ada), mulai tahun 2018 . 


\subsection{Analisis Peningkatan Kualifikasi Teknisi Pesawat Udara di Indonesia}

Berdasarkan observasi lapangan, saat ini kualifikasi teknisi pesawat udara di Indonesia mayoritas adalah berkualifikasi STM/SMK, dan sebagian kecil berkualifikasi D-II, khususnya para teknisi senior. Hal tersebut dapat dijumpai pada mayoritas maskapai penerbangan swasta, juga pada maskapai penerbangan milik pemerintah (GMFAA/ Garuda Group). Kondisi ini juga dikuatkan dengan adanya program BAM SMU/SMK di Bagian Learning Service GMFAA yang sudah berlangsung beberapa tahun terakhir, untuk menghasilkan teknisi pesawat udara berkualifikasi SMU/SMK.

Tabel 4. Contoh kurikulum D-III AMTO
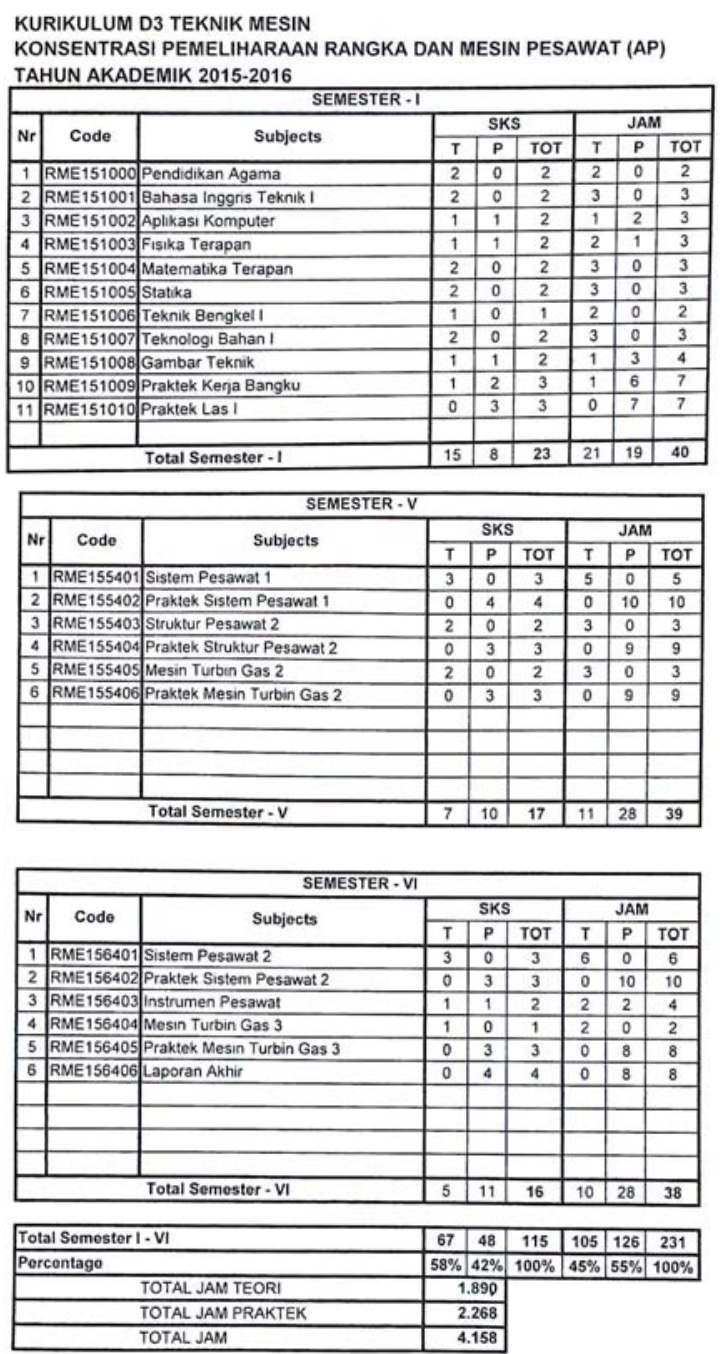

Sumber: Anonim, 2016 [8]
Dengan adanya program D-III AMTO kelas kerjasama, maka akan dihasilkan teknisi pesawat udara yang kompeten dengan kualifikasi pendidikan D-III. Seiring dengan waktu, program BAM SMU/ SMK akan dikurangi bahkan dihentikan. Bahkan pada beberapa tahun terakhir maskapai Garuda sudah menetapkan standar kualifikasi teknisi baru minimal berkualifikasi pendidikan D-III.

Dengan demikian sangat jelas bahwa keberadaan program D-III AMTO kelas kerjasama GMFAA dengan 6 perguruan tinggi sangat berperan strategis dalam meningkatkan kualifikasi teknisi pesawat udara di Indonesia, dari sebelumnya mayoritas lulusan SMU/SMK dan D-II, kedepan akan menjadi minimal berkualifikasi D-III.

\section{Kesimpulan}

Upaya peningkatan jumlah dan kualifikasi teknisi pesawat udara di Indonesia telah dilakukan oleh GMFAA dengan menjalin kerjasama dengan Perguruan Tinggi dan menyelenggarakan kelas BAM Dosen dan BAM D-III di Perguruan Tinggi. Sebanyak 16 Dosen dari 6 Perguruan Tinggi telah dilatih untuk disiapkan sebagai pengajar kelas AMTO di kampus masing-masing. Pada tahun pertama (2015) telah dibuka kelas AMTO di enam kampus dengan mahasiswa sejumlah 226 dan pada tahun kedua (2016) sejumlah 216. Mulai tahun ke-4 (2018) akan dihasilkan tenaga ahli perawatan pesawat dengan kualifikasi D-III minimal 200 orang, sehingga sangat membantu percepatan pemenuhan kebutuhan teknisi pesawat udara di Indonesia. Peningkatan jumlah teknisi yaitu minimal 200 orang/tahun (mengurangi gap antara supply dan demand sebesar 50\%). Peningkatan kualifikasi teknisi yaitu dari mayoritas SMU/SMK dan D-II menjadi minimal berkualifikasi D-III.

Studi ini sangat bagus untuk memberikan gambaran tentang upaya peningkatan jumlah dan kualifikasi teknisi pesawat udara di Indonesia, namun belum membahas dan meneliti dampak langsung program terhadap dunia penerbangan di tanah air.

\section{Saran}

Untuk kelanjutan studi yang lebih baik, perlu dilakukan studi mendalam tentang pelaksanaan kelas AMTO di Perguruan Tinggi penyelenggara dan dilakukan penelitian terkait dampak penyelenggaraan 
kelas AMTO di Perguruan Tinggi terhadap dunia penerbangan di Indonesia.

Ucapan Terima kasih

Penulis mengucapkan terima kasih kepada seluruh peserta BAM Dosen dan semua pihak yang telah berkenan memberikan informasi untuk keperluan studi ini.

\section{DAFTAR PUSTAKA}

[1] Rohmawati, Reni, Septian Hermawan, Remigius, and Raharjo, Gatot, 2014, Tenaga Profesional Penerbangan: Targetnya Ekspor Pekerja Terampil, Majalah Angkasa Online, http:// www.http://www.angkasa.co.id/, diakses tanggal 23 Agustus 2016.

[2] Anonim, 2015, Indonesia Kekurangan 7.500 Teknisi Penerbangan, Tabloid Tranportasi Indonesia (Trasindo) Online, http://www. transindoonline.com/2015/01/indonesiakekurangan-7500-teknisi.html/, diakses tanggal 23 Agustus 2016.

[3] Tejo, Amir, 2014, Indonesia Kekurangan Teknisi Pesawat, Majalah Tempo.Co Online, http:// www.tempo.co/29 April 2014//indonesiakekurangan-teknisi-pesawat._bisnis_tempo. co.htm/, diakses tanggal 23 Agustus 2016.
[4] Anonim, 2016, Admisi Polinema, Informasi Penerimaan Mahasiswa Baru Program Kerjasama POLINEMA dan GMF Aero Asia Online, http://www.polinema.ac.id/, diakses tanggal 23 Agustus 2016.

[5] Nur Cahyaningrum, Septi; Sutadji, Edi; Solichin, 2013, Hubungan Antara Life Skill Siswa Dengan Hasil Belajar Praktikum Pengelasan Di Smkn 1 Trenggalek, Jurnal Teknik Mesin Universitas Negeri Malang, Tahun ke 21, Nomer 2, Oktober 2013, halaman 211-223

[6] Linda, 2015, Training Attendant List Basic Aircraft Maintenance fo Instructor Airframe Powerplant, GMFLearning Services, PT. GMF Aero Asia, Jakarta.

[7] Fuad, 2016, Kurikulum BAM DOSEN, Bagian Learning Services, PT. GMF Aero Asia,Jakarta.

[8] Anonim, 2016, Kurikulum D-III Teknik Mesin Konsentrasi Pemeliharaan Rangka dan Mesin Pesawat Tahun Akademik 20162017, Bagian Akademik Kelas Kerjasama Polinema dan GMF, Politeknik Negeri Malang, Malang. 